\title{
David Riesman and the Concept of Bibliographic Citation
}

\section{Raymond G. McInnis and Dal Symes}

In this article, we discuss how, over time, both the concept and the function of bibliographic citation change and correspond to Riesman's three types of personal character. First in the tradition-directed period, titles come before authors, since the writer is seen as merely the instrument of authority. In the inner-directed period, a transition occurs, with the author's name coming before the title. Finally, in the present time, which corresponds to Riesman's other-directed period, the format for the bibliographic citation becomes formalized, and the concept of its function changes dramatically. Ultimately the citation becomes a symbol for both substantive content and for intellectual property.

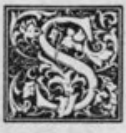

cholars generally agree that The Lonely Crowd ${ }^{1}$ has significantly influenced the way they understand and discuss contemporary society. ${ }^{2}$ David Riesman's observations on the stages of character development in the social order can also be illuminating when applied to the development of scholarly activity as it is demonstrated in published records. Especially pertinent are how referencing and other bibliographic practices and conventions, from a historical perspective, reflect his models of tradition-, inner-, and otherdirected character.

To understand how the theories of Riesman and other thinkers apply to scholarly conventions, we will develop a framework that first discusses the function of concept in scholarly discourse, with special attention to how, through evolution, bibliographic citations have come to function as concepts, including how bibliographic ci- tations have taken on a symbolic function, frequently substituting for substantive content. ${ }^{3}$ Finally, we will present evidence that demonstrates how Riesman's theory of the historical development of human character provides a possible explanation of why our concept of the bibliographic citation has developed through these permutations. ${ }^{4}$

\section{THE FUNCTION OF CONCEPTS IN SCHOLARLY DISCOURSE}

Concepts are the basic building blocks of knowledge. Many scholars, especially philosophers of science, have pointed out how concepts are fundamental to inquiry and explanation in all scholarly disciplines. ${ }^{5}$ Essentially they perceive the purpose of research is to produce knowledge. The results of research (findings) are presented in scholarly publications as explanations. These explanations, in turn, organize knowledge. The principles and

Raymond G. McInnis is Social Sciences Librarian and Head of the General Reference Department and Dal Symes is Humanities Librarian at Wilson Library, Western Washington University, Bellingham, Washington 98225. The authors wish to acknowledge the comments of Paul Durbin, Dick Feringer, Jim Inverarity, William Keith, Dan Larner, Ron Merchart, John Richardson, and especially David Riesman. 
theories that emerge from this organization of knowledge are called concepts.

Specifically, says Eugene Meehan, an American sociologist, concepts identify and classify the topics we think about by placing them in specific times and places. They present definitions and perform the range of tasks that Abraham Kaplan's term organizing experience implies. ${ }^{6}$

Without concepts, Meehan argues, "man could hardly be said to think." In addition, according to British anthropologist Edmund Leach, when concepts are converted into material objects, as they are when published, they attain "relative permanence," or, to put it another way, abstract thoughts are given a concrete quality. ${ }^{8}$ Once turned into this sort of material form, Leach claims, concepts can be subjected to technical operations otherwise beyond "the capacity of the mind acting by itself."

\section{PRESCRIPTIVE NATURE OF MEANING AND VALIDITY OF CONCEPTS}

Throughout scholarly discourse, the meanings of concepts are set forth in a prescriptive rather than a descriptive sense. A concept has meaning only because scholars prescribe the meaning attached to it. ${ }^{9}$ In other words, a concept's meaning is valid only if scholars in the same field agree to it having the same meaning.

The American lexicographer Sidney I. Landau further singles out distinctions between prescriptive and descriptive meanings in scholarly discourse. Landau speaks of "extracted" or "imposed" meanings. To illustrate, he distinguishes between the way words are defined in lexical (standard) dictionaries and the way words (as labels for concepts) are treated in subject-field (specialized) dictionaries. In lexical dictionaries, general words are defined by citations from specific texts illustrating how particular words are used. The particular meanings are extracted from the context in which these words are employed in sentences. In subject-field dictionaries, on the other hand, terms take on special meanings "imposed on the basis of expert advice," or are prescribed. ${ }^{10}$

In The Lonely Crowd, Riesman's concepts regarding the development of human character are excellent examples of terms with specialized imposed or prescribed meanings. As is the tradition, when a scholar's special definitions of particular terms are considered valid, other scholars attach the same meanings when they employ these terms.

\section{THE SYMBOLIC FUNCTION OF THE BIBLIOGRAPHIC CITATION IN SCHOLARLY DISCOURSE}

In scholarship, the accepted method of identifying a published source is the bibliographic citation. When we cite another publication in the text of our discourse, we identify the particular source by giving sufficient details needed for others to locate it.

John Ziman, the British physicist and popularizer of science, presents evidence that the collective nature of scientific discourse "is made very obvious by the systematic use of references or citations in scientific papers." 11 In scientific (and scholarly) discourse, papers do not stand alone; they are, instead, embedded in the literature of the subject. The knowledge included also contains all relevant previous studies-not just the actual works cited but also the works referred to in the cited articles as well. Arguments presented and facts listed need to be documented, not unlike "the precedents in English Common Law."

Further, Ziman argues, the "pattern" citations take has "its own internal logic," which may not resemble the theoretical logic of the subject. The "historical order and connectivity" into which citations fall may not be the categories into which the field will eventually settle. A particular paper, for example, clever but not entirely sound, may dominate the subject for years, only to be corrected; later, except in histories, it scarcely warrants mention. On the other hand, continues Ziman, research can long lie neglected and forgotten, but when discovered it becomes "a great well of knowledge.",13

\section{SCHOLARSHIP AS PERSUASION}

If we accept this understanding about the function of bibliographic citation, a li- 
brary is "not primarily a quarry," or "a factory. ${ }^{\prime 14}$ Instead, we should consider it a store, a memory where, as new results from scholarly activity are transferred to it, each unit is constantly updated. Thus, says Ziman, when consulting an article in a back issue of a journal, a scientist is not seeking what an author was thinking about when the paper was published; instead, the scientist is looking for evidence to support his or her own research topic. Similarly, an attorney is searching the literature when looking for the title deeds of a property a client is purchasing. The citation of references, "which validates many of the claims that he will make, embeds it in the pre-existing consensus." The "orderliness of this process, the intellectual structure implicit in the library, the cata$\log$, the encyclopedia, the treatise, give meaning to the research of the past and the motive for research in the future."

\section{"Ziman's testimony demonstrates how scholarship is essentially per- suasion by argument, buttressed by support from authoritative papers in the field."}

Ziman's testimony demonstrates how scholarship is essentially persuasion by argument, buttressed by support from authoritative papers in the field. This observation is not unique to Ziman. In a sense, the citation is the modern equivalent of the classical rhetorical device that uses an appeal to authority to bolster one's argument. Aristotle calls such a means of persuasion atechnoi pisteis, or nonartistic or nontechnical persuasion, since the rhetorician did not have to invent supporting arguments. ${ }^{15}$ Others who have also observed how scholarship is persuasion include Arthur Koestler, C. Wright Mills, Thomas Kuhn, Jerome Bruner, F. C. Bartlett, Peter McKellar, Lawrence Kubin, Abraham Kaplan, Michael Polanyi, Chaim Perelman, William T. Scott, Jerome Ravetz, and G. R. Elton. ${ }^{16}$

Another example of persuasion comes from examining the processes involved in scholarly writing. In an empirical study of how graduate students write, David S.
Kaufer, a professor of rhetoric at Carnegie-Mellon, finds that the writing process falls into four phases: (1) summarize the work of other authors, (2) synthesize their ideas to find common principles, (3) analyze the merit of their positions, and (4) contribute new views to the discussion. ${ }^{17}$ While one must admit that, to a greater or lesser degree, variations in this formula exist among scholars, the format nonetheless reflects scholarly discourse in general and is not just characteristic of student writing. We get more evidence to justify this claim from the citation studies of Nigel Gilbert, Henry Small, and Blaise Cronin.

\section{REFERENCING \\ AS PERSUASION}

In a succession of papers late in the 1970 s, British sociologist G. Nigel Gilbert argued that referencing, such as citing a scientific paper, is really a form of persuasion. ${ }^{18} \mathrm{~A}$ scholar with true, important results still has to persuade the scholarly community to share this opinion, for it is only when some consensus has been achieved that the research findings will be transformed into scientific knowledge. In other words, scholarly papers really contain "knowledge claims" staked out by authors who must wait for their claims to be certified by the scholarly community.

One of the riskiest knowledge claims involved Galileo's insistence that the authorship and authority of his conceptions about the universe be recognized. This led to his famous trial by the Catholic Inquisition. Ernst Cassirer, the German philosopher, points out that when Galileo insisted on publishing the "scandalous" On the Two Systems of the Universe, he was suggesting a dangerous idea: scientific scholarship is the product of a new priesthood qualified to interpret nature as a revelation of God, comparable to the Testament revelation that, up to then, was the church's own preserve.

Galileo's knowledge claim, in effect, argued that no authority, divine or human, can supersede the authority that comes through experiment and mathematical deduction. From observable facts comes an image of reality "that possesses a unique and necessary truth." When we strive to 
understand and explain the universe and its parts, Galileo argued, why should we "'begin with the word of God?" Instead, he insisted, knowledge comes from experience and can never be questioned by argument from biblical texts. ${ }^{19}$

\section{THE SIGNIFICANCE OF THE CITATION CONTEXT}

In 1978, Henry Small, a historian of science, argued that insufficient attention is given in citation analyses to the textual content of the citation context (i.e., how a writer labels the publications cited). Because of this lack of attention, citation analyses miss "the role citations play as symbols of concepts or methods. "20 Moreover, Small adds, citation contexts perform cognitive functions, arising from the formal requirement imposed on the scholar to embed references to earlier literature in a written text. This leads to the citing of works that embody ideas the author is discussing. The cited documents become symbols for these ideas. In a text, Small says,

The footnote number has the function of pointing to a portion of the text in which it is embedded and at the same time corresponding to a specific document usually given at the bottom of the page or grouped at the end of the article. The footnote number should unambiguously point to a word, phrase, sentence, or other unit of text to show what ideas are to be connected with the cited document. ${ }^{21}$

By referring to other sources, authors give further meaning to their own writing, and also give their sources meaning by citing them. For example, continues Small, "if I use Lowry's method of protein determination and cite his paper, I am not only telling the reader where he can find a description of the method, but I am stating what his paper is about, that is, a method for protein determination." When we view referencing this way, we can see it as a labeling process. The language pointed to by the footnote number characterizes the documents cited-or constitutes the author's interpretation of the cited work. In citing a document, an author, therefore, creates its meaning.

According to Small, viewing "citations as concept symbols is a more direct inter- pretation of citation practice than previous 'classification' attempts."' Small quotes Eugene Garfield: "A cited document is analogous to a subject heading in an indexing system." Studying the citation context of highly cited documents is a method of observing the transformation of scholars' work into knowledge.

\section{BIBLIOGRAPHIC CITATIONS AS FOOTPRINTS}

We are indebted to Blaise Cronin, a British librarian, for analyzing the scattered literature about citation practice. "Metaphorically," Cronin argues, "citations are frozen footprints in the landscape of scholarly achievement" and "bear witness to the passage of ideas." ${ }^{22}$ With footprints, we can deduce direction "from the configuration and depth of the imprint." Ideally, we can also construct a picture of those who have passed by, and the distribution and variety furnish clues as to whether the advance was orderly and purposive. Citations give substantive expression to the process of innovation, and, if properly marshaled, provide scholars "with a forensic tool of seductive power and versatility."

In scholarly discourse, then, when we cite another work we are substituting the citation for the concepts the work contains. ${ }^{23}$ Citing the book is a device for telling readers that you are discussing one or more of the book's concepts. To illustrate, let's look at The Lonely Crowd, the source of at least three major concepts; as we shall see below, such citation practice is a mirror image of certain characteristics Riesman attributes to his notion of the otherdirected character.

\section{THE LONELY CROWD}

When David Riesman, a sociologist at Harvard University, published The Lonely Crowd in 1950, he argued that historically in Western civilization the majority of persons have evolved through three types of individual character: the traditiondirected, the inner-directed, and the other-directed. Riesman defines character as those components of our behavior and belief systems that organize our drives and satisfactions. 
Tradition-directed individuals behave according to norms expected of the age in which they live, of their family, of their beliefs, of their social customs. When tradition-directed, we conform to slowly changing behavior practices passed from generation to generation. In Riesman's view, tradition-directed societies mainly existed before the Renaissance, or, if they exist today, they are labeled underdeveloped.

As the Renaissance unfolded, examples of the inner-directed individual appeared. Early in this individual's life a set of fixed goals-success, piety, self-controlbecomes part of an internalized code of conduct. These characteristics are passed on to us by parents and other authorities. "The inner-directed social order produced people equipped with an inner psychological gyroscope that would carry them through all sorts of new situations," Joseph Featherstone argues, "men and women of unbending principle," where "'the ideals of 'work,' 'success,' 'independence,' 'manliness,' 'character,' focus on patterns of drives and strivings. ${ }^{\prime 24}$ In Riesman's view, the inner-directed character came into full flower in the nineteenth century.

The other-directed individual, characteristic of American society, appeared in the mid-twentieth century. Production, a significant feature of the social order of the inner-directed person, became secondary to consumption, a feature of the social order of the other-directed person. As otherdirected individuals, we respond to signals emerging from a circle far wider than just our parents. Guidance comes from peers and contemporaries, personal and professional associations, and the mass media. Conformity, in effect, is externalized. The other-directed character "signals a broad shift from nature to society, from competition to cooperation. ${ }^{\prime 25,26}$

\section{THE BIBLIOGRAPHIC CITATION IN THE TRADITION-DIRECTED PERIOD}

Recognition of the author's name as the primary means of identifying publications occurred slowly. The Western concept of author entry came from the Greeks. In the

\section{"Recognition of the author's name as the primary means of identifying publications occurred slowly."}

non-Western world and also in the medieval world of Christian Europe, the title identified a book, not the author. This tradition developed out of the notion of the supremacy of a deity, in which an author is important only as an instrument of a publication, and not as an individual. Similar to art and architecture, a book was considered to come from God and the author was only a conduit for God's word. Mirroring this belief, bibliographies put a work's title before the author's name, or even ignored it just as the creators of works of art were ignored. Ruth Strout, a cataloging authority, points out that even today in the East the traditional entry for a book is its title. Whenever, under the influence of modern Western librarianship, a book in an Asian library is entered under author-a tradition that "rests upon belief in the importance of the individual" - it is considered very progressive and Western, or democratic. ${ }^{27}$

Such practices provide evidence of the tradition-directed social order David Riesman presents in The Lonely Crowd.

\section{THE BIBLIOGRAPHIC CITATION IN THE INNER-DIRECTED PERIOD}

The first bibliography to list books by author is attributed to Johannes Trithemius in the fifteenth century. ${ }^{28}$ Surnames as entry words, instead of forenames, were introduced by Konrad Gesner in 1545. But, says Johannes Dewton, only in the eighteenth century did the "surname as entry word become generally accepted."

According to Alice Mona East, the practice of citing authorities, with reference to the exact place a text is cited, developed only after the invention of printing with moveable type. ${ }^{29}$ (Before, the pages on which specific texts appeared varied too much to be referred to with any assurance.) East examined the citation practices 
of more than fifty works published in the sixteenth and seventeenth centuries. She investigated "the use of citations to books as evidence, as authority for a statement, rather than on their use as sources or as decoration in literature." Investigation found citations used-as suggested by classical rhetoricians-as evidence to persuade by authority rather than for sources of authority or for pretentious decoration. "Probably because books became more generally known," she argues, "the feeling that a piece of writing belonged in some sense to its author gradually developed." Here, again, the evidence confirms Riesman's theory of the historical emergence of the inner-directed individual as it is manifested in scholarship. The transition from one citation practice to the other was lengthy. East states that only with the advent of the eighteenth century did the published records of scholarship begin to approach the modern standard of citation. $^{30}$

When they discovered the value of direct observation of phenomena-and having few predecessors to refer to-the early scientists wrote "fairly straight-forward descriptions of the methods and results of the experiment undertaken, with an occasional reference to the classics or the Bible as a sort of decoration. ${ }^{\prime \prime 31}$ But, claims East, in the period of her study, few publications cited other scientific works.

Instead, "the earliest true citations appear in works of religion, where the appeal to authority is natural, and in books of controversy, where it is necessary for clarity. ${ }^{32}$ Biographies and historical works, in which writers must use other sources, included citations, and these citations came at an earlier date than those in books of medicine or other practical arts, where the work was produced from the writer's own knowledge. Scientific works, which appeared from about the middle of the seventeenth century, confined themselves to reports of the immediate investigation.

Between 1700 and 1750 , all scholarly writers except experimental scientists used citations that, although they did not reach the modern standard in form (the chief deficiency being the persistent use of abbreviated titles), they did make clear what sources were being cited. Derek J. de Solla Price notes that the transformation of the scientific paper into its modern form occurred in the 1860s. "As late as 1900, some of the respected journals contain not one scientific paper of the present variety." But, claims Price, a historian of science, distinctions can be made about "the mode of cumulation of the papers, " each of which, in turn, "is one of several points of departure for the next." Our most telling "manifestation of this scholarly bricklaying is the citation of references.' ${ }^{\prime 33}$ This evidence gives us, in very broad brush strokes, the outlines of features of otherdirectedness: (1) greater social cohesiveness and scholarly rigor among individuals working in the same areas; (2) the use of agreed-upon procedures, cooperatively producing increasingly larger bodies of knowledge; and (3) a responsiveness and loyalty beyond the boundaries of university to a national or even international community.

\section{THE BIBLIOGRAPHIC CITATION IN THE OTHER-DIRECTED PERIOD}

In the 1940s, dramatic changes in our concept of bibliographic citation began to occur. In separate articles, two librarians presented new interpretations of the functions of bibliographic citation. According to both J. F. Fulton ${ }^{34}$ and William Postell, ${ }^{35}$ bibliographic citations serve two basic functions: (1) to identify the source of a given statement and (2) to describe "the nature and scope of the printed document in which the statement is found."

But, says Fulton, citations are also "an integral part of the scientific evidence of a paper." Thus if "writers quote from the literature without giving readers any opportunity of verifying statements, important elements in the chain of logic are omitted. ${ }^{\prime \prime 6}$ Such practices cast suspicion about the author's credibility. To Postell, "the purpose of bibliographic citation is to give authority for every statement of fact quoted." A citation, then, is an integral part of the logic of the discipline's rhetoric. A bibliographic citation is a "link in the chain of evidence" associated with a 
topic. ${ }^{37}$ Thus, for the first time, the notion of citation is articulated as an integral part of scholarship. Like Riesman's definition of other-directedness, it must also outwardly conform to the established format of the particular discipline in which the scholar writes. Further, both Fulton and Postell's arguments about the function of bibliographic citations as "evidence" in scholarship in the 1940s are harbingers of significant new insights about the concept of the bibliographic citation that occurred in the 1950s.

\section{THE BIBLIOGRAPHIC CITATION AS SUBJECT HEADING}

When he presented his concept of citation indexes in 1955, Eugene Garfield introduced the notion of bibliographic citation as subject heading. A major breakthrough, this concept is the first of two in the decade that changed our view of the function of bibliographic citations in scholarly discourse. Subtitled "A New Dimension in Documentation through Association of Ideas," his article argues that "the utility of a citation index in any field must also be considered from the point of view of the transmission of ideas." ${ }^{\prime \prime 3}$

\section{"The concept of bibliographic cita- tion as subject heading indicates an increasing prevalence of agreed- upon norms of scholarship."}

The concept of bibliographic citation as subject heading indicated an increasing prevalence of agreed-upon norms of scholarship. These, in turn, produced in the minds of scholars working in similar fields the idea that (1) they shared similar methods and concepts, and (2) components of their knowledge could be specified by citing the publications that were responsible for contributing to this knowledge. When cited, these discrete knowledge components function as subject headings. When the language of such discourse takes on prescribed meanings of a specific discipline, we see further evidence of Riesman's other-directed charac- teristics becoming manifest in that area of scholarship.

As a means of identifying or otherwise specifying a research topic, Garfield finds that the bibliographic citation possesses greater power than the arbitrarily assigned subject heading. He says, in effect, that bibliographic citation is a more precise way of identifying a concept contained by a specific publication than is a subject heading arbitrarily added by another party. A bibliographic citation, in other words, can substitute for a subject heading.

A decade later Garfield again argued that we have to recognize the underlying concept symbolized by a bibliographic citation. ${ }^{39}$ As librarians, he says, our traditional concept of a subject is so ingrained that we fail to realize that a word is merely a symbol for a concept. To demonstrate his point, Garfield cites an analogy from chemistry. Chemists, he claims, fall into the same trap and often forget that a chemical formula is only symbolic of the real thing.

As an example of the difficulties in correlating complex concepts with arbitrarily assigned word-structured indexing languages, Garfield argues, consider the concept protein determination of the Folin phenol reagent, or the Lowry method. ${ }^{40}$ First published in 1951

the paper is the most frequently cited work in the 1967 literature. No term exists for it in the (thesaurus) of Index Medicus. The symbol: Lowry, 1951, JBC v 193, p. 265 also identifies its exact address! Unquestionably, Index Medicus does provide for indexing papers on protein determination methods, but that is a vastly more generic concept than the Lowry method, or derivates thereof.

\section{THE BIBLIOGRAPHIC CITATION AS LABEL FOR INTELLECTUAL PROPERTY}

In 1957, sociologist Robert Merton introduced the notion of the bibliographic citation as the symbol for intellectual property, a theme that, with variations, was later developed by other writers. ${ }^{41}$ As the decade's second major breakthrough in shaping our understanding of the function of bibliographic citations, this concept 
contributes significantly to arguments in our discussion.

In our opinion, the view of bibliographic citation as subject heading and intellectual property connects to the other-directed individual, the third and final of Riesman's three kinds of character. Scholarship, today, is a collective enterprise, which implies that knowledge is socially constructed. The production of knowledge under these conditions means that participants in specific areas of scholarship necessarily follow certain agreed-upon patterns of behavior and share a common set of values. These behaviors and values are usually learned from peers by apprenticeship. While scholarship is a collective enterprise, which means other-directedness in individual contributions conforming to a set of norms, the ownership of these contributions is vested in individuals whose property is maintained through a system of citations. And, following Leach, Small, Gilbert, and Garfield, citations become shorthand referents for abstract material. They acquire a form that allows us to manipulate them more easily without losing meaning.

\section{'ORIGINALITY' IN SCHOLARSHIP}

Inner-direction and other-direction are, of course, both modes of conformity, with the main distinction being conforming to. Inner-directed people, in Hartshorne's view, just "seem more individualistic than the other-directed person." Why? Because "the pressures to which he conformed are less obvious." This individual conforms to such inner-directed standards as those dictated by family practices or beliefs, or social norms prevailing at the time. Under inner direction, an individual "has no more rational freedom of choice than the other-directed person." The individual himself "is likely to be following his own self-determined course, but Riesman himself insists that this is a delusion. ${ }^{\prime 42}$ With the inner-directed character, cooperation is limited because competition is more important. Communication takes place only with the intimate group, and the final product is perceived as a unique contribution. This kind of activity, it is true, still prevails in the research and development departments of large manufacturing firms.

In scholarly communities, people conform to certain standards and procedures based on an understanding that this conformity is less confining than innerdirectedness. While conformity exists, it exists in order to enhance cooperation and communication among a national, or even international, community, rather than to respond mainly to the expectations of one's local peer group. ${ }^{43}$ (We acknowledge, of course, that scholarly activity has its darker side, including excessive secrecy, deliberate distribution of incorrect data, and referees acting as "gatekeepers." As an example, we need only cite Watson's The Double Helix. $)^{44}$

A scholar's role is to advance scholarship, and, in this context, originality is at a premium. Recognition for originality is indicated through the citation of one's publications. With such citation, one establishes property rights. Merton writes about scientific scholarship, but others argue similar practices prevail throughout scholarship. ${ }^{45}$ Critics generally credit Norman Kaplan, for example, for bringing into focus scattered commentary about the social function of citation practices in scholarship, with special concern for the nature of intellectual property. ${ }^{46}$

In Merton's view, such recognition can be seen in the language employed by scientists in speaking of their work: ${ }^{47}$

Ramsay, for example, asks Rayleigh's "permission to look into atmospheric nitrogen" on which Rayleigh has been working; the young Clerk Maxwell writes William Thomson, "I do not know the game laws and patent laws of science . . . but I certainly intend to poach among your electrical images"; Norbert Weiner describes "differential space, the space of Brownian motion" as "wholly mine in its purely mathematical aspects, whereas I was only a junior partner in the theory of Banach spaces."

Other evidence confirming this notion as it relates to scientific fields (and which we believe, to a greater or lesser degree, applies in scholarship in general) comes from Pierre Bourdieu. Through Bourdieu's lens, scientific activity is cast in a competition model. Bourdieu, a French 
sociologist, argues that scientific activities are "directed towards the acquisition of scientific authority. ${ }^{\prime 48}$

The struggle for authority is about scientific property rights. To achieve authority in a scientific field means that recognition for this authority must be extracted from one's competitors, that is, only other scientists working in the same field have "the means of symbolically appropriating (one's) work and assessing its merits."

At stake here, Bourdieu continues, is "in fact the power to impose the definitions of science best united to legitimize the assumption of an ascendant position in the hierarchy of scientific values. ${ }^{149}$ Appropriating scientific authority means appropriating scientific property rights. And, as we agreed above, the labels for these property rights are bibliographic citations. In effect, scientific authority is "a particular kind of capital which can be accumulated, transmitted, and even reconverted into other kinds of capital under certain conditions." 50

In the scholarly world, one cannot borrow, trespass, poach, steal, or otherwise claim a concept belonging to another without giving due credit where, because of property rights, credit is due. In short, Merton concludes, property rights in scholarship can be reduced to just one issue: "the recognition by others of the scholar's distinctive part in having brought the result into being. ${ }^{\prime 51}$ With such evidence, we can conclude that in what Riesman labels an other-directed social order, where conformity is externalized, scholars, through bibliographic citations, are able to maintain individual property rights to their intellectual creation. ${ }^{52}$

"In what Riesman labels an otherdirected social order, where conformity is externalized, scholars, through bibliographic citations, are able to maintain individual property rights to their intellectual creation."

SUMMARY AND CONCLUSION

Historically, concepts symbolized through bibliographic citation correlate with the three models of individual character Riesman develops in The Lonely Crowd. Today, in scholarly discourse, bibliographic citations are, as concept symbols, recognized as integral to the production of knowledge.

Concepts are essential components of scholarly discourse. Socially constructed, they are the principles and theories resulting from scholarly activity. Concepts are the building blocks of knowledge.

The meanings given concepts are prescriptive, not descriptive. In seeking to understand and explain the subject matter of their inquiry, scholars impose special meaning on certain terms. If these special meanings are considered valid, the meanings achieve a sort of concrete quality, conveniently allowing us to discuss them with others in the field.

As examples of imposed meanings, Riesman's three major concepts in The Lonely Crowd are examined. Reisman characterizes the individual in the social order according to an understanding of personal behavior in the three major epochs of Western civilization. In the first epoch, individuals were tradition-directed, with behavior influenced by authority figures. In the second epoch, individuals tended to be more inner-directed, relying more on guidance from parents and other family members. In the third epoch, which began in the middle of the twentieth century, individuals were more other-directed. When other-directed, values and other determinants of our behavior come from groups outside our immediate circle.

A function of bibliographic citations in scholarly discourse is to symbolize or otherwise represent concepts, methods, or other features from a given work. That is, if a writer wishes to incorporate something from another work, it must be cited. By citing other works, writers transmit the cited material rapidly and efficiently. Bibliographic citations also perform cognitive functions: for example, to persuade readers about the validity of a thesis, a writer embeds the text with references from works supporting this reasoning. By being cited these documents become symbols for these views. According to Small, 
two results are achieved: (1) by citing the works of others, writers give additional meaning to their own writing, and (2) by citing other works, authors enhance the importance of these cited works. Bibliographic citations may then function both as subject headings (Garfield) and as labels for intellectual property (Merton).

Finally, by citing other works, authors create, in Cronin's words, "footprints in the landscape of scholarly achievement." This practice allows others to trace the path of scholarship either backward or forward, determine what progress has been achieved in a given area of inquiry, and possibly predict potential future developments.

Loyalty is no longer primarily to one's department or university. Instead, loyalty is transferred to the scholarly community to which one belongs. Part of this loyalty requires following rigorous standards in the conduct of scholarly inquiry, including the format for citing bibliographic references. Along with agreed-upon concepts and procedures, these standards, in turn, are part of the system for transmitting knowledge.

In the Western world, throughout the period covered by written records, the concept of the function of bibliographic citations corresponds with Riesman's three types of personal character:

First, in the tradition-directed period, direction comes from figures of supremacy; ordinary people, including writers, are said to be merely the instruments of authority. In these conditions, in bibliographies, the titles of published works come before the names of authors.

Second, in the inner-directed period, which began roughly when printing with moveable type was introduced, a distinct change in bibliographic format occurred: in bibliographies, authors' names were listed first, indicating that a work belonged to the writer.

Third, in the other-directed period, the format of the bibliographic citation became more formalized and the concept of its function changed dramatically. ${ }^{53}$ In the social order of the other-directed period, although they operate independently, people are said to conform to standards emanating from the group to which they give their loyalty.

However, as much as people are said to conform to particular patterns of behavior in this other-directed period, procedures are needed to define specifically what contributions these individuals are responsible for. To Merton, these practices indicate originality in scholarship. Citation contexts specify these contributions with considerable precision. And to borrow an idea from another work without proper acknowledgment is to plagiarize. Such conventions and beliefs justify the notion that, in the other-directed period, the bibliographic citation is a label for intellectual property.

\section{REFERENCES AND NOTES}

1. David Riesman, Renel Denny, and Nathan Glazer, The Lonely Crowd: A Study of the Changing American Character (New Haven, Conn.: Yale Univ. Pr., 1950).

2. Leon Botstein, "The Children of the Lonely Crowd," Change 10:16 (May 1978); Eric Larrabee, "David Riesman and His Readers" in Culture and Social Character: The Work of David Riesman Reviewed, ed. Seymour M. Lipset and Leo Lowenthal (Glencoe, Ill.: Free Pr., 1961), p.404-16; Thomas Harthshorne, The Distorted Image: Changing Conceptions of the American Character since Turner (Cleveland, Ohio: Case Western Univ. Pr., 1968), p.173; Peter Rose, "David Riesman Reconsidered," Society 19:57 (Mar./Apr. 1982); Richard H. Pells, The Liberal Mind in a Conservative Age: American Intellectuals in the 1940s and 1950 (New York: Harper, 1985), p.238-48; Jonathan Yardley, "Reconsiderations: The Lonely Crowd," New Republic 166:29 (Mar. 4, 1972).

3. We acknowledge that in scholarly discourse differences of opinion prevail among scholars about the necessity and/or utility of authors citing the works of others. These views represent a minority, however, and-regardless of whatever merit these views are said to have-are not considered in this discussion. In addition, much good scholarly writing does not formally cite the work of others. In these cases, regardless of the lack of explicit, formal citations, it can be demonstrated that such writing implicitly incorporates the work of others. Finally, we acknowledge that both the motives 
for citation and the broad range of types of citations are not addressed. For discussion of these matters, see Blaise Cronin, The Citation Process (London: Taylor Graham, 1984).

4. In this discussion, bibliographic citation means the printed record that identifies a publication, whether in footnotes, bibliographies, library card catalogs, or computerized databases. For publications for which an individual author is identifiable as the originator of the material (that is, periodical article, chapters in books, or entire books), the bibliographic citation includes such details as author, title of article or book, periodical title or book publisher, date of publication, and of course any other information necessary to indicate a publication's uniqueness.

5. Eugene J. Meehan, Explanation in Social Science, A System Paradigm (Homewood, Ill.: Dorsey Pr., 1968); Edward N. Saveth, American History and the Social Sciences (Glencoe, Il. Free Pr., 1964), p.5; Robert Berkhofer, A Behavioral Approach to Historical Analysis (New York: Free Pr., 1969), p.271.

6. Meehan, Explanation in Social Science, p.35.

7. Ibid.

8. Edmund Leach, Culture and Communication: The Logic by Which Symbols Are Connected (Cambridge, Eng.: Cambridge Univ. Pr., 1976), p.37.

9. Abraham Kaplan, The Conduct of Inquiry (Scranton, Pa.: Chandler Pub., 1964), p.46.

10. Sidney I. Landau, Dictionaries: The Art and Craft of Lexicography (New York: Scribner, 1984), p.20.

11. John Ziman, Public Knowledge (Cambridge, Eng.: Cambridge Univ. Pr., 1968), p.58.

12. Ziman, Public Knowledge, p.158.

13. Ibid., p.59-60.

14. Ibid., p.103-4; Charles B. Osburn, Academic Research and Library Resources (Westport, Conn.: Greenwood Pr., 1979), p.49; Stephen Stoan, "Research and Library Skills: An Analysis and Interpretation, College \& Research Libraries 45:100 (Mar. 1984).

15. Edward P. J. Corbett, Classical Rhetoric for the Modern Student, 2d ed. (New York: Oxford Univ. Pr., 1971), p.33-34.

16. Raymond G. McInnis, New Perspectives for Reference Work in Academic Libraries (Westport, Conn.: Greenwood Pr., 1978), p.83-86.

17. David S. Kaufer, The Architecture of Argument (New York: HBJ, 1988), as cited in New York Times 136: C1 (Apr. 7, 1987). We get more insight about scholarship as persuasion from the current increase in interest in the study of rhetoric, especially as it is said to apply in the conventions employed by scholars working in "interpretive communities," that is, the networks of scholars drawn together because of similar research interests. In 1987 the University of Wisconsin Press published the results of the 1984 University of Iowa Humanities Symposium on the Rhetoric of the Human Sciences. Edited by John S. Nelson, Alan Megill and Donald N. McCloskey, this volume surveys rhetorical conventions employed in a number of disciplines, but primarily the social sciences. In chapter one, to set the theme for the volume, the editors declare that "Scholarship uses argument, and argument uses rhetoric. The 'rhetoric' is not mere ornament or manipulation or trickery. It is rhetoric in the ancient sense of persuasive discourse. In matters of mathematical proof to literary criticism, scholars write rhetorically." John S. Nelson and others, "Rhetoric of Inquiry," in The Rhetoric of the Human Sciences: Language and Argument in Scholarship and Public Affairs, ed. John S. Nelson and others [Madison, Wisc.: Univ. of Wisconsin Pr., 1987], p.3.) Other titles that explore these same themes include: Richard A Cherwitz and James W. Hikins, Communication and Knowledge: An Investigation in Rhetorical Epistemology (Columbia, S.C.: Univ. of South Carolina Pr., 1986) and Winifred Bryan Horner, ed., The Present State in Historical and Contemporary Rhetoric (Columbia, Mo.: Univ. of Missouri Pr., 1983). As an issue, scholarship as persuasion is of course of major concern to academic libraries, especially as it relates to at least two matters of national significance in academe today associated with student learning: the "writing-across-thecurriculum" movement and with teaching "critical thinking" skills.

18. G. Nigel Gilbert, "The Transformation of Research Findings into Scientific Knowledge," Social Studies of Science 6:281 (1976); 7:115 (1977).

19. Ernst Cassirer, "Galileo: A New Science and a New Spirit," American Scholar 12:5-19 (Winter 1942); but also see Elizabeth L. Eisenstein, The Printing Press as an Agent of Change: Communications and Cultural Transformations in Early-Modern Europe, V.2 (Cambridge, Eng.: Cambridge Univ. Pr., 1979), p.698.

20. Henry Small, "Cited Documents as Concept Symbols," Social Studies of Science 3:328 (1978). See also his "Citation Context Analysis," Progress in Communication Sciences 3: 287-310 (1982).

21. Small, "Cited Documents as Concept Symbols," p.328.

22. Blaise Cronin, "The Need for a Theory of Citing," Journal of Documentation 37:16 (1981);

Citation Process, p. 25. 
23. In this context, concept is not used according to its abstract or theoretical formulation. Instead, following Small, "Cited Documents as Concept Symbols," p.329, concept includes "experimental findings, methodologies, types of data, metaphysical notions, theoretical statements or equations-or, in general when dealing with citations, any statement which may be taken as characterizing or describing the cited document."

24. Joseph Featherstone, "John Dewey and David Riseman: From the Lost Individual to the Lonely Crowd, " in On the Making of Americans: Essays in Honor of David Riseman, ed. Herbert J. Gans and others (Philadelphia: Univ. of Pennsylvania Pr., 1979), p.17-18.

25. Ibid., p.18.

26. Below we'll see that the other-directed character is very appropriate for understanding how individuals operate in scholarly communities.

27. Ruth Strout, "The Development of the Catalog and Cataloging Codes," Library Quarterly 26:257 (1956); Johannes L. Dewton, "The Influence of the Structure of the Catalog on the Form of Catalog Entry," Festschrift Josef Stummvoll . . . , 1970, p.489; Ilse Bry, "The Emerging Field of Sociobibliography: Reassessment and Reorientation of Access to Knowledge in the Social Sciences," in Access to the Literature of the Social Sciences and Humanities: Proceedings, New York, 1972 (Flushing, N.Y.: Queens College Pr., 1974), p.14.

28. Strout, "Development of the Catalog and Cataloging"; Dewton, "The Influence of the Structure of the Catalog."

29. Alice Mona East, Bibliographical Citation in English Books in the Sixteenth and Seventeenth Centuries (Unpublished thesis, Univ. of Michigan, Dept. of Library Science, 1952), p.1-2.

30. Ibid., p.3.

31. Ibid., p.43.

32. Ibid., p.71.

33. Ibid.,p.72; Derek J. de Solla Price, Little Science, Big Science (New York: Columbia Univ. Pr., 1963), p.64-65. Price places the date at the middle of the eighteenth century. See also Norman Kaplan, "Norms of Citation Behavior," American Documentation 16:180 (July 1965).

34. John F. Fulton, "The Principles of Bibliographical Citation," College \& Research Libraries 6:185 (1945); Cyril C. Barnard, "Bibliographical Citation," The Librarian and the Book World 39:105 (1950).

35. William Postell, "Clarifying Bibliographical Citation," College \& Research Libraries 6:249 (1945).

36. Fulton, "Principles of Bibliographical Citation," p.185.

37. Postell, "Clarifying Bibliographical Citation," p.249.

38. Eugene Garfield, "Citation Indexes for Science," Science 122: 109-10 (1955).

39. Eugene Garfield, "Citation Indexing and the Sociology of Science," International Congress of Medical Librarianship, 3d, Amsterdam, Proceedings (Amsterdam: Excerpta Medica, 1969), p.189.

40. Garfield, "Citation Indexing and the Sociology of Science," p.192.

41. Robert K. Merton, "Priorities in Scientific Discovery: A Chapter in the Sociology of Science," American Sociological Review 22:639 (Dec. 1957); Kaplan, "Norms of Citation Behavior"; Derek J. de Solla Price, "Networks of Scientific Papers," Science 149:510 (1965); Ziman, Public Knowledge p.158; Jerome R. Ravetz, Scientific Knowledge and Its Social Problems, (New York: Oxford Univ. Pr., 1973), p.256-57.

42. Hartshorne, Distorted Image, p.177.

43. Osburn, Academic Research and Library Resources, p.xvii.

44. James D. Watson, The Double Helix: A Personal Account of the Discovery of the Structure of DNA (New York: Atheneum, 1968).

45. For a thorough discussion of the literature of citation practices, see Cronin, The Citation Process.

46. Kaplan, "Norms of Citation Behavior."

47. Merton, "Priorities in Scientific Discovery," p.640.

48. Pierre Bourdieu, "The Specificity of the Scientific Field and the Social Conditions of the Progress of Reason," Social Science Information 14:21 (1975). Emphasis added.

49. Ibid., p.23.

50. Ibid., p. 25 .

51. Merton, "Priorities in Scientific Discovery," p.640.

52. Harriet A. Zuckerman has studied the patterns of name ordering in the citation of multiauthored scientific papers. Her evidence suggests that, contrary to what one might assume, current practice does not dictate that first place in the order of names goes the most prominent investigator. Instead she finds that "a name's visibility in a series depends first on its relative visibility, defined by its ranks in the series and, secondly, on its intrinsic visibility, " which it owes to the fact that being familiar, the practice of "[abandoning] first place to others increases as the capital possessed increases, and with it the symbolic profit automatically accruing to its possessor, regardless of his 
place in the order." Harriet A Zuckerman, "Patterns of Name Ordering among Authors of Scientific Papers: A Study of Social Symbolism and Its Ambiguity," American Journal of Sociology, 74: 276-291 (Nov. 1968), as cited by Bourdieu, "Specificity of the Scientific Field," p.26.

53. Merton, "Priorities in Scientific Discovery," p.640.

\section{IN FORTHCOMING ISSUES OF COLLEGE \& RESEARCH LIBRARIES}

Tomorrow's Research Library: Vigor or Rigor Mortis?

by Richard D. Hacken

A Current Awareness Service for Faculty and Staff: The Stout Experience by John J. Jax and Van C. Houlson

Subject Searching in an Online Catalog with Authority Control

by Noelle Van Pulis and Lorene E. Ludy

Bibliographic Verification for Interlibrary Loan: How Necessary Is It?

by Jo Ann Bell and Susan Speer

Measuring Collections Use at Virginia Tech

by Paul Metz and Charles Litchfield

Instructional Design: Increasing the Effectiveness of Bibliographic Instruction

by Marian I. Miller and Barry D. Bratton

More Benefits of Automation

by Malcom Getz 